REFLEKSI HUKUM

Jurnal Ilmu Hukum
p-ISSN 2541-4984 | e-ISSN 2541-5417

Volume 3 Nomor 1, Oktober 2018, Halaman 49-66

DOI: https://doi.org/10.24246/jrh.2018.v3.i1.p49-66

Open access at: http://ejournal.uksw.edu/refleksihukum Penerbit: Fakultas Hukum Universitas Kristen Satya Wacana

\title{
PERLINDUNGAN HUKUM HAK CIPTA BUKU PENGETAHUAN DITINJAU DARI UNDANG-UNDANG NOMOR 28 TAHUN 2014 TENTANG HAK CIPTA
}

\author{
Achmad Chosyali \\ Magister Ilmu Hukum Universitas Diponegoro \\ Korespondensi: jolichosyali@gmail.com
}

\begin{abstract}
Abstrak
Hak cipta adalah hak eksklusif bagi pencipta untuk mengumumkan atau memperbanyak ciptaannya dalam bidang ilmu pengetahuan, seni, dan sastra yang antara lain dapat terdiri dari buku, program komputer, ceramah, kuliah, pidato, dan ciptaan lain yang sejenis dengan itu, serta hak terkait dengan hak cipta. . Buku merupakan suatu karya intelektual dari pencipta atau pemegang hak cipta yang memiliki hak eksklusif yang terdiri dari dua hak yaitu hak ekonomi dan hak moral sehingga hak ini harus mendapatkan perlindungan. Dengan adanya hak eksklusif itu peneliti ingin mengetahui bagaimana perlindungan dan prospek perlindungan hukum hak cipta buku pengetahuan ditinjau dari Undang-Undang Nomor 28 Tahun 2014 tentang Hak Cipta. Metode yang digunakan dalam penelitian ini adalah metode yuridis normatif. Dengan adanya perlindungan hukum ini diharapkan mampu memberikan suatu kesadaran dan pemahaman yang lebih baik di masa yang akan datang.
\end{abstract}

Kata Kunci: Prospek; Perlindungan Hukum; Buku Pengetahuan; Hak Cipta.

\begin{abstract}
Copyright is the exclusive right of the creator to announce or reproduce his creations in the fields of science, art, and literature, which among others can consist of books, computer programs, lectures, lectures, speeches and other similar works, as well as rights related to copyright. A book is an intellectual work of a creator or copyright holder who has exclusive rights consisting of two rights, namely economic rights and moral rights so that this right must be protected. Noticing the existence of exclusive rights, the researcher is willing to know about the protection and prospects of the copyright protection of knowledge books are reviewed from Law Number 28 of 2014 concerning copyright. The method used in this study is normative juridical method. With this legal protection, it is expected to be able to provide a better awareness and understanding in the future.
\end{abstract}

Keywords: Prospects; Legal Protection; Knowledge Books; Copyright. 


\section{PENDAHULUAN}

Hak Kekayaan Intelektual (HKI) pada hakikatnya merupakan suatu hak dengan karakteristik khusus dan istimewa karena hak tersebut diberikan oleh negara. Negara berdasarkan ketentuan Undang-Undang (UU), memberikan hak khusus tersebut kepada yang berhak sesuai dengan prosedur dan syarat-syarat yang harus dipenuhi. ${ }^{1}$ Dalam HKI ada dua kategori pengertian, pertama adalah pengertian HKI dalam istilah sehari-hari yaitu segala sesuatu yang berasal dari hasil pemikiran manusia seperti ide, invensi, puisi, merek, desain, semi konduktor dan sebagainya. Kedua adalah pengertian HKI dalam konsep hukum yaitu seperangkat aturan hukum yang memberikan jaminan hak eksklusif untuk mengeksploitasi HKI dalam jangka waktu tertentu berdasarkan jenis-jenis HKI. Terdapat kelompok besar dalam pembagian HKI, pertama yaitu Hak Kekayaan Industri (industrial property right) yang meliputi paten, merek, desain, desain tata letak sirkuit dan rahasia dagang, kedua adalah Hak Cipta yang memberikan perlindungan untuk karya tulis, karya sastra dan karya seni (literary and artistic work). ${ }^{2}$

HKI mempunyai fungsi utama untuk memajukan kretifitas dan inovasi yang bermanfaat bagi masyarakat secara luas sedangkan hak cipta secara khusus juga berfungsi sebagai alat untuk memperkenalkan, memperkaya, dan menyebarluaskan kekayaan budaya bangsa. ${ }^{3}$ Kekayaan intelektual merupakan kreatifitas yang dihasilkan dari olah pikir manusia dalam rangka memenuhi kebutuhan dan kesejahteraan hidup manusia. Kreatifitas manusia yang muncul sebagai aset intelektual seseorang telah lama memberi pengaruh yang signifikan terhadap peradaban manusia, antara lain melalui penemuan-penemuan (inventions) dan hasil-hasil di bidang karya cipta dan seni (art and literary work). ${ }^{4}$ Bentuk penghargaan dari hasil kreativitas manusia, baik dalam bentuk penemuan-penemuan (inventions) maupun hasil karya cipta dan seni (art and literary work), terutama ketika hasil krativitas itu digunakan untuk tujuan komersil. 5

Pengakuan dan juga reward (penghargaan) terhadap hasil kreatifitas seseorang dengan tatanan hukum yang disebut rezim hukum hak kekayaan intelektual. Rezim hukum ini memberikan perlindungan terhadap hasil karya penemu (inventor) atau pencipta dari pihak lain yang secara tidak sah menggunakan ataupun memanfaatkan hasil karyanya. Selain itu rezim hukum HKI juga memberikan perlindungan terhadap kepentingan ekonomi dari hasil temuan ataupun karya cipta penemu atau pencipta. Perlindungan hukum bertujuan untuk memberikan rangsangan untuk menghasilkan

1 Sentosa Sembiring, Hak Kekayaan Intelektual dalam Berbagai Perundang-Undangan (Yrama Widya 2002) 13.

2 Denny Kusmawan, 'Perlindungan Hak Cipta Atas Buku’ (2014) 19 Jurnal Perspektif $137,137$.

Ibid., 137.

Achmad Gusman Guntur Siswandi dalam Kholis Roisah, Konsep Hukum Hak Kekayaan Intelektual (HKI) (Setara Press 2015) 1.

$5 \quad$ Kholis Roisah, Konsep Hukum Hak Kekayaan Intelektual (HKI) (Setara Press 2015) 2. 
temuan atau karya cipta yang lebih inovatif. 6

Hak cipta adalah hak eksklusif bagi Pencipta untuk mengumumkan atau memperbanyak ciptaannya dalam bidang ilmu pengetahuan, seni, dan sastra yang antara lain dapat terdiri dari buku, program komputer, ceramah, kuliah, pidato, dan ciptaan lain yang sejenis dengan itu, serta hak terkait dengan hak cipta. ${ }^{7}$ Dengan demikian bahwa pengertian hak cipta adalah hak yang dimiliki seorang pencipta atau pemegang hak cipta untuk mengumumkan dan memperbanyak hasil ciptaannya. ${ }^{8}$ Sifat dasar yang melekat pada hak cipta (the nature of copyright), yaitu: ${ }^{9}$

a. Hak cipta adalah hak milik (property right);

b. Hak cipta adalah hak yang terbatas waktunya (limited duration);

c. Hak cipta adalah sebuah hak yang bersifat eksklusif (exclusive right);dan

d. Hak cipta adalah sebuah kumpulan hak didalam sebuah karya (a multiple right, a bundle of right in one work).

Adapun yang dilindungi hak cipta adalah ide yang telah berwujud dan asli. ${ }^{10}$ Salah satu bentuk pelanggaran terhadap hasil karya cipta dari pencipta atau pemegang hak cipta adalah buku pengetahuan. Pada prakteknya banyak buku pengetahuan yang diperbanyak secara masal oleh pihak tertentu baik untuk tujuan akademis ataupun komersial tertentu guna mendapatkan keuntungan tanpa seizin dari pencipta atau pemegang hak cipta.

Pasal 44 ayat (1) UU No. 28 Tahun 2014 tentang Hak Cipta (UU Hak Cipta), menjelaskan penggunaan, pengambilan, penggadaan, dan/atau pengubahan suatu ciptaan dan/atau produk hak terkait secara seluruh atau sebagian yang substantial tidak dianggap sebagai pelanggaran Hak Cipta jika sumbernya disebutkan atau dicantumkan secara lengkap untuk keperluan:

a. Pendidikan, penelitian, penulisan karya ilmiah, penyusunan laporan, penulisan kritik, atau tinjauan suatu masalah dengan tidak merugikan kepentingan yang wajar dari Pencipta atau Pemegang Hak Cipta;

b. Kemanan serta penyelenggaraan pemerintahan, legislatif, dan peradilan;

c. Ceramah yang hanya untuk tujuan pendidikan dan ilmu pengetahuan; atau

d. Pertunjukan atau pementasan yang tidak dipungut bayaran dengan ketentuan tidak merugikan kepentingan yang wajar dari Pencipta.

Adapun dengan adanya Pasal 44 ayat (1) huruf a tersebut menimbulkan perbedaan perspektif sehingga banyak terjadi penyimpangan terhadap penggandaan buku pengetahuan dengan alasan pendidikan dan lain sebagainya yang sebenarnya penggandaan tersebut merugikan hak eksklusif dari pencipta

Ibid., 2.

Asian Law Group Pty. Ltd, Hak Kekayaan Intelektual Suatu Pengantar (PT. Alumni 2011) 6.

Ade Uswatun Sitorus, 'Hak Cipta dan Perpustakaan' (2015) 9 Jurnal Iqra 1, 2.

Stewart dalam Otto Hasibuan, Hak Cipta di Indonesia (PT. Alumni 2014) 57.

10 Otto Hasibuan, Hak Cipta di Indonesia (PT. Alumni 2014) 65. 
atau pemegang hak cipta. Dengan adanya penyimpangan terhadap penggunaan buku pengetahuan tersebut membuat pencipta atau pemegang hak cipta tidak mendapatkan hak eksklusif yang seharusnya didapatkan. Hak eksklusif yang diberikan bagi Pencipta terdiri atas Hak Ekonomi dan Hak Moral. ${ }^{11}$

Maraknya bentuk pelanggaranpelanggaran terhadap buku masih sering terjadi. Pelanggaran terhadap buku pengetahuan pada prakteknya banyak terjadi dikalangan masyarakat. Adapun pelanggaran tersebut salah satunya adalah penggandaan buku pengetahuan tanpa seizin pencipta atau pemegang hak cipta. Pelanggaran tersebut juga tidak terlepas dari carut marut penegakan hukum di Indonesia saat ini dan kurangnya pemahaman dari masyarakat terkait dengan pelanggaran penggandaan buku pengetahuan. Perlindungan hukum terhadap hasil karya cipta buku pengetahuan seharusnya dapat diberikan dengan tidak melanggar hak eksklusif dari pencipta atau pemegang hak cipta. Perlindungan hukum terhadap HKI pada dasarnya berintikan pengakuan terhadap hak atas kekayaan dan hak untuk menikmati kekayaan itu dalam waktu tertentu, artinya selama waktu tertentu pemilik atau pemegang hak atas HKI dapat mengizikan ataupun melarang orang untuk menggunakan karya intelektualnya. ${ }^{12}$

Berdasarkan uraian permasalahan tersebut, penulis tertarik untuk menge- tahui lebih mendalam terkait dengan bagaimanakah perlindungan hukum hak cipta buku pengetahuan ditinjau dari UU Hak Cipta dan bagaimanakah prospek perlindungan hukum hak cipta buku pengetahuan yang akan datang.

Metode yang digunakan dalam penelitian ini adalah metode yuridis normatif. Menurut Soetandyo Wignyosoebroto menjelaskan bahwa penelitian yang menggunakan metode yuridis normatif suatu penelitian doktrinal yang mengkaji hukum yang dikonsepkan sebagai kaidah perundang-undangan menurut doktrin postivisme. ${ }^{13}$ Nama lain dari penelitian hukum normatif adalah penelitian hukum doktriner, juga disebut sebagai penelitian perpustakaan atau studi dokumen, penelitian ini dilakukan mengacu kepada peraturan-peraturan yang tertulis atau bahan-bahan hukum yang lain.

\section{PEMBAHASAN}

\section{Hukum Hak Cipta tentang Buku Pengetahuan}

Hak cipta telah melekat erat dengan objek materiil yang didalamnya ciptaan ini terbentuk, sehingga apabila dimisalkan pada suatu perjanjian kerja, atas suatu hak cipta otomatis akan beralih haknya ketika suatu barang atau benda diserahkan dari tangan yang mengerjakan kepada pemberi kerja. Pengertian hak adalah kewenangan yang diberikan kepada seseorang untuk dipergunakan secara bebas. Diantara hak-hak yang diakui oleh masyarakat global adalah

\footnotetext{
11 Belinda Rosalina, Perlindungan Karya Arsitektur Berdasarkan Hak Cipta (PT. Alumni 2010$) 109$.

12 Denny Kusmawan, Op. Cit., 138.

13 Soetandiyo Wignyosoebroto, Hukum: Paradigma, Metode, dan Dinamika Masalahnya (Huma 2002) $147-160$.
} 
Intelectual Property Rights, hak yang secara khusus diperuntukkan bagi perlindungan hasil karya akal manusia. Intelectualy Property Rights dapat diartikan sebagai Kekayaan Intelektual (KI). Indonesia sendiri menganut asas hukum kontinental dengan lahirnya suatu karya cipta berkeyakinan bahwa pada saat itu pulalah telah lahir hak cipta atas suatu karya cipta.

Fitzgerald menjelaskan teori perlindungan hukum bahwa hukum bertujuan mengintegrasikan dan mengkoordinasikan dalam masyarakat suatu lalu lintas kepentingan, perlindungan terhadap kepentingan tertentu hanya dapat dilakukan dengan cara membatasi berbagai kepentingan di lain pihak. Aliran ini dipelopori oleh Plato, Aristoteles, dan Zeno. Menurut aliran hukum alam menyebutkan bahwa hukum itu bersumber dari Tuhan yang bersifat universal dan abadi, serta antara hukum dan moral tidak boleh dipisahkan. Para penganut aliran ini memandang bahwa hukum dan moral adalah cerminan dan aturan secara internal dan eksternal dari kehidupan manusia yang diwujudkan melalui hukum dan moral. ${ }^{14}$

Menurut Djumhana dijelaskan bahwa doktrin-doktrin yang berkembang dalam perlindungan hak cipta, yaitu:

a. Doktrin publisitas (right of publicity);

b. Making avaible right dan merchandishing right;

c. Doktrin penggunaan yang pantas (fair use/fair dealing); d. Doktrin kerja atas dasar sewa (the work made for hire doctrine);

e. Perlindungan (hak) karakter;

f. Pengetahuan tradisional (traditional knowledge); dalam lingkup keterkaitan hak cipta;

g. Cakupan-cakupan baru dalam perlindungan hak cipta; software free, copyleft, open source.

Perlindungan hukum sangat penting, untuk menjalankan dan memberikan perlindungan hukum, dibutuhkan suatu tempat atau wadah dalam pelaksanaannya. Menurut pendapat Phillipus M. Hadjon bahwa perlindungan hukum bagi rakyat sebagai tindakan pemerintah yang bersifat preventif dan represif. Perlindungan hukum yang preventif bertujuan untuk mencegah terjadinya sengketa, yang mengarahkan tindakan pemerintah bersikap hati-hati dalam pengambilan keputusan berdasarkan diskresi, dan perlindungan yang represif bertujuan untuk menyelesaikan terjadinya sengketa, termasuk penanganannya di lembaga peradilan. ${ }^{15}$ Adapun maksud dari perlindungan hukum terhadap hak cipta yaitu untuk mendorong individu-individu di dalam masyarakat yang memiliki kemampuan intelektual dan kreativitas agar lebih bersemangat menciptakan sebanyak mungkin karya cipta yang berguna bagi kemajuan bangsa. ${ }^{16}$

Di Indonesia, perlindungan hak cipta hanya diberikan pada suatu karya cipta yang telah memiliki bentuk yang khas (material form), bersifat

14 Satjipto Rahardjo, Imu Hukum (PT. Citra Aditya Bakti 2000) 53.

15 Phillipus M. Hadjon, Perlindungan Hukum Bagi Rakyat Indonesia (PT. Bina Ilmu 1987) 29.

16 Fajar Alamsyah Akbar, Perlindungan Hukum terhadap Hak Cipta Menurut Pasal 12 Undang-Undang Nomor 28 Tahun 2014 (2016) 3 JOM Fakultas Hukum 2, 4. 
pribadi, menunjukkan keasliannya yang lahir berdasarkan kemampuan, kreativitas, atau keahlian (mental effort) sehingga berwujud sebagai ciptaan yang dapat dilihat, dibaca, atau didengar. Titik lain divergensi adalah tersedianya pedoman UU tentang keadilan suatu kesepakatan atau penggunaan harus dievaluasi. Karena ketentuan transaksi yang adil pada umumnya tidak memiliki definisi atau peraturan perundang-undangan yang menentukan bagaimana keadilan ditetapkan, pendekatan yang tepat untuk menilai keadilan transaksi sebenarnya dengan karya-karya yang dilindungi. Ketentuan penggunaan wajar dalam UU Hak Cipta Amerika Serikat menetapkan empat faktor yang harus disertakan dalam penentuan keadilan:

a. Tujuan dan karakter penggunaan.

b. Hak cipta dan karya cipta.

c. Jumlah dan substansial bagian dari pekerjaan.

d. Pengaruh penggunaan pada potensi pasar.

David Bainbridge dalam justifikasi perlindungan KI dapat digambarkan dengan ungkapan sederhana. Intinya setiap orang harus diakui dan berhak memiliki apa yang dihasilkannya. Bila hak itu diambil darinya, ia tak lebih dari seorang budak. Ungkapan ini menjadi semakin penting mengingat dalam prespektif KI, apa yang dihasilkan sepenuhnya berasal dari otak atau kemampuan intelektual manusia. ${ }^{17}$

Pentingnya perlindungan hukum bagi kaum lemah, juga ditemukan dalam pemikiran Grotius, Thomas Hobbes, Spinoza, dan John Locke. Mereka adalah ahli-ahli yang muncul di era kebangkitan Teori Hukum Alam abad XVII. Grotius mengatakan bahwa hukum itu ada karena adanya suatu perjanjian atau kontrak, perjanjian ini terjadi semata-mata karena manusia itu adalah makhluk sosial, sehingga selalu ada keinginan untuk hidup bermasyarakat. Hukum dan negara bertujuan untuk ketertiban dan keamanan. ${ }^{18}$ Perlindungan hukum hak cipta mutlak diperlukan karena tanpa perlindungan hukum tentu akan mempengaruhi para pencipta untuk berkreasi di bidang intelektual.

John Locke mengatakan bahwa hak milik dari seorang manusia terhadap benda yang dihasilkannya itu sudah ada sejak manusia itu lahir. Jadi benda dalam pengertian di sini tidak hanya benda yang berwujud tetapi juga benda yang abstrak, yang disebut dengan hak milik atas benda yang tidak berwujud yang merupakan hasil dari intelektualitas manusia. Teori dasar yang ada dalam KI yang dikemukakan oleh John Locke yaitu teori hak alami (natural right theory), teori karya (labor theory), teori pertukaran social (social exchange theory), dan teori fungsional (functional theory).

HKI adalah harta KI yang dilindungi oleh UU. Perlindungan hukum terhadap hak milik intelektual didasari pada dua alasan. Pertama, karena dalam karya intelektual terdapat moral right yang mencerminkan tentang kepribadian dari si pencipta. Kedua, karena faktor ekono-

17 Henry Soelistyo, Hak Cipta Tanpa Hak Moral (Rajawali Pers 2011) 11.

18 S. Arinanto dan N. Triyanti, Memahami Hukum dari Konstruksi Sampai Implemantasi (PT. Raja Grafindo Persada 2001) 11. 
mi atau commercial right yang dikandung oleh karya intelektual itu. Faktor yang terakhir inilah yang mendorong negara-negara di dunia untuk memberikan perlindungan hukum secara penuh dan tegas terhadap karya intelektual. ${ }^{19}$

KI adalah hak eksklusif yang diberikan suatu hukum atau peraturan kepada seseorang atau sekelompok orang atas karya ciptaannya. Jadi pada umumnya KI berhubungan dengan perlindungan penerapan ide dan informasi yang memiliki nilai komersial, KI adalah kekayaan pribadi yang dapat dimiliki dan diperlakukan sama dengan bentuk kekayaan lainnya. ${ }^{20} \mathrm{KI}$ adalah hak milik hasil pemikiran (intelektual) yang melekat pada pemiliknya, bersifat tetap dan eksklusif. KI merupakan serang-kaian hak dan kepentingan yang sah terkait dengan produk yang dihasilkan dari aktivitas intelektual manusia. KI hak yang berasal dari kegiatan kreatif suatu kemampuan daya pikir manusia yang diekspresikan kepada khalayak umum dalam berbagi bentuknya, bermanfaat, berguna untuk menunjang kehidupan dan memiliki nilai ekonomi. ${ }^{21}$

KI hanya diberikan dan berlaku kepada pemiliknya, si pencipta, penemu ataupun pemegang karya intelektual lainnya. Pihak mana pun dilarang untuk meniru, memakai dan mempergunakan dalam perdagangan suatu karya intelektual tanpa seizin pemiliknya. Eksklusifitas KI memberi hak paling unggul kepada pemiliknya. KI merupakan bagian dari harta kekayaan (kebendaan). Harta kekayaan adalah benda milik orang atau badan yang memiliki nilai ekonomi, diakui dan dilindungi oleh hukum berdasarkan bukti yang sah, serta dapat dialihkan kepada pihak lain, baik karena perjanjian maupun karena UU.

HKI mendasarkan diri pada prinsip salah satunya yaitu prinsip keadilan (the principle of natural justice) yaitu Pencipta yang menghasilkan suatu karya berdasarkan kemampuan intelektualnya wajar memperoleh imbalan baik berupa materi maupun bukan materi, seperti adanya rasa aman karena dilindungi, dan diakui atas hasil karyanya. Hukum memberikan perlindungan kepada Pencipta berupa suatu kekuasaan untuk bertindak dalam rangka kepentingannya yang disebut hak, perlindungan ini pun tidak terbatas di dalam negeri pencipta sendiri melainkan dapat meliputi perlindungan diluar batas negaranya. Adapun prinsip lain yaitu prinsip ekonomi (the economic argument) yaitu HKI yang diekspresikan kepada khalayak umum dalam berbagai bentuknya, memiliki manfaat dan nilai ekonomi. Adanya nilai ekonomi pada HKI merupakan suatu bentuk kekayaan bagi pemiliknya. Misalnya dalam bentuk pembayaran royalti.

Menurut UU Hak Cipta, ciptaan adalah setiap hasil karya cipta di bidang ilmu pengetahuan, seni, dan sastra yang dihasilkan atas inspirasi, kemampuan, pikiran, imajinasi, kecekatan, keterampilan, atau keahlian yang diekspresikan dalam bentuk nyata.

19 Saidin, Aspek Hukum Hak Atas Kekayaan Intelektual (PT. Raja Grafindo Persada 2010) 111.

20 T. Lindsey, dkk, Hak Kekayaan Intelektual (Alumni 2011) 3.

21 Djumhana dan R. Djubaedilah, Hak Milik Intelektual (PT. Citra Aditya Bakti 2003) 21-22. 
Pasal 40 UU Hak Cipta menjelaskan bahwa ciptaan yang dilindungi adalah sebagai berikut:

a. Buku, pamflet, perwajahan karya tulis yang diterbitkan, dan semua hasil karya tulis lainnya;

b. Ceramah, kuliah, pidato, dan Ciptaan sejenis lainnya;

c. Alat peraga yang dibuat untuk kepentingan pendidikan dan ilmu pengetahuan;

d. Lagu dan/atau musik dengan atau tanpa teks;

e. Drama, drama musikal, tari, koreografi, pewayangan, dan pantomim;

f. Karya seni rupa dalam segala bentuk seperti lukisan, gambar, ukiran, kaligrafi, seni pahat, patung, atau kolase;

g. Karya seni terapan;

h. Karya arsitektur;

i. Peta;

j. Karya seni batik atau seni motif lain;

k. Karya fotografi;

1. Potret;

m. Karya sinematografi;

n. Terjemahan, tafsir, saduran, bunga rampai, basis data, adaptasi, aransemen, modifikasi dan karya lain dari hasil transformasi;

o. Terjemahan, adaptasi, aransemen, transformasi, atau modifikasi ekspresi budaya tradisional;

p. Kompilasi Ciptaan atau data, baik dalam format yang dapat dibaca dengan Program Komputer maupun media lainnya; q. Kompilasi ekspresi budaya tradisional selama kompilasi tersebut merupakan karya yang asli;

r. Permainan video; dan

s. Program Komputer.

Buku merupakan ciptaan yang dilindungi berdasarkan Pasal 40 UU Hak Cipta, adapun buku merupakan suatu karya intelektual dari pencipta atau pemegang hak cipta yang memiliki hak eksklusif yang terdiri dari dua hak yaitu hak ekonomi dan hak moral. Hak eksklusif adalah bahwa hanya pemegang hak ciptalah yang bebas melaksanakan hak cipta tersebut, sementara orang atau pihak lain dilarang melaksanakan hak cipta tersebut tanpa persetujuan pemegang hak cipta. ${ }^{22}$ Secara nyata bahwa hak ekonomi merupakan hak untuk mendapatkan manfaat ekonomi atas ciptaan serta produk hak terkait. Artinya bahwa buku dalam hal ini termasuk pula didalam buku pengetahuan mempunyai nilai ekonomis dan dapat dieksploitasi. Adapun hak moral adalah hak yang melekat pada diri pencipta yang tidak dapat dihilangkan atau dihapus tanpa alasan apapun, walaupun hak cipta atau hak terkait telah dialihkan atau dapat disebut juga dengan hak yang bersifat manunggal antara ciptaan dan diri pencipta, atau dapat pula disebut sebagai integritas dari si pencipta.

Berdasarkan Pasal 5 ayat (1) huruf a, huruf b, dan huruf e UU Hak Cipta, hak moral pencipta berlaku tanpa batas

22 Tommy Hottua Marbun dan T. Keizeirina Devi Azwar, 'Perlindungan Hukum Hak Cipta Terhadap Karya Cipta Lagu dan Musik dalam Bentuk Ringtone Pada Telepone Seluler' (2013) 1 Transparency Jurnal Hukum Ekonomi 2. 
waktu. Adapun hak moral pencipta berlaku selama berlangsungnya jangka waktu hak cipta atas ciptaan yang bersangkutan sebagaimana dimaksud dalam Pasal 5 ayat (1) huruf c dan huruf d UU Hak Cipta. Terkait dengan perlindungan hak cipta atas suatu ciptaan diatur pada Pasal 58 UU Hak Cipta menjelaskan bahwa:

a. Perlindungan Hak Cipta atas ciptaan:

1. Buku, pamflet, dan semua hasil karya tulis lainnya;

2. Ceramah, kuliah, pidato, dan ciptaan sejenis lainnya;

3. Alat peraga yang dibuat untuk kepentingan pendidikan dan ilmu pengetahuan;

4. Lagu atau musik dengan atau tanpa teks;

5. Drama, drama musikal, tari, koreografi, pewayangan, dan pantomime;

6. Karya seni rupa dalam segala bentuk seperti lukisan, gambar, ukiran, kaligrafi, seni pahat, patung, atau kloase;

7. Karya arsitektur;

8. Peta.

b. Karya seni batik atau seni motif lain, berlaku selama hidup pencipta dan terus berlangsung selama 70 (tujuh puluh) tahun setelah pencipta meninggal dunia.

c. Dalam hal ini ciptaan dimiliki oleh dua orang atau lebih, perlindungan Hak Cipta berlaku selama hidup penciptanya yang meninggal dunia paling akhir dan berlangsung selama 70 (tujuh puluh) tahun sesudahnya.

d. Perlindungan hak cipta atas ciptaan yang dimiliki atau dipegang oleh badan hukum berlaku selama 50 (lima puluh) tahun sejak pertama kali dilakukan pengumuman.

Berdasarkan pengaturan perlindungan hak cipta dalam UU Hak Cipta tersebut menjelaskan bahwa buku merupakan karya cipta yang dilindungi oleh hukum. Penggandaan buku pengetahuan tanpa seizin dari pencipta dan atau pemegang hak cipta guna mendapatkan keuntungan komersil menandakan terjadinya perbuatan melawan hukum dan dapat dikenakan sanksi pidana atau perdata. Pasal 1 angka 12 UU Hak Cipta menjelaskan bahwa penggandaan adalah proses, perbuatan, atau cara menggandakan suatu salinan ciptaan dan/atau fonogram atau lebih dengan cara dan dalam bentuk apapun, secara permanen atau sementara. Pasal 1 angka 23 menjelaskan bahwa pembajakan adalah penggandaan ciptaan dan/atau produk hak terkait secara tidak sah dan pendistribusian barang hasil penggandaan dimaksud secara luas untuk memperoleh keuntungan ekonomi.

Pada prakteknya bahwa pembajakan terhadap buku banyak terjadi di kalangan masyarakat di seluruh Indonesia. Penegakan hukum dalam hal pembajakan buku pengetahuan seakanakan tidak berjalan sebagaimana mestinya sehingga hak cipta buku pengetahuan tidak mendapatkan perlindungan hukum. Penggandaan buku pengetahuan untuk mendapatkan hak ekonomi harus dilaksanakan berdasarkan lisensi yang diberikan dari pemegang hak cipta atau pemilik. Adapun Pasal 1 angka 20 UU Hak Cipta menjelaskan bahwa lisensi adalah izin tertulis yang diberikan oleh pemegang hak cipta atau 
pemilik hak terkait kepada pihak lain untuk melaksanakan hak ekonomi atas ciptaannya atau produk hak terkait dengan syarat tertentu.

Adapun terhadap pembajakan buku pengetahuan akan dikenakan ganti rugi. Ganti rugi merupakan pembayaran sejumlah uang yang dibebankan kepada pelaku pelanggaran hak ekonomi pencipta, pemegang hak cipta dan/atau pemilik hak terkait berdasarkan putusan pengadilan perkara perdata atau pidana yang berkekuatan hukum tetap atas kerugian yang diderita pencipta, pemegang hak cipta dan/atau pemilik hak terkait. Sesuai dengan Pasal 9 ayat (2) UU Hak Cipta, setiap orang yang melaksanakan hak ekonomi sebagaimana dimaksud pada ayat (1) wajib mendapatkan izin pencipta atau pemegang hak cipta. Artinya setiap orang yang mendapatkan hak ekonomi dari suatu ciptaan atas suatu karya cipta termasuk dalam ini buku pengetahuan tanpa mendapatkan izin dari pencipta atau pemegang hak cipta adalah tindakan yang dilarang oleh UU Hak Cipta, sehingga dapat dikenakan sanksi pidana atau perdata.

Salah satu sifat atau asas yang melekat pada hak kebendaan adalah asas droit de suite, asas hak mengikuti bendanya. Hak untuk menuntut akan mengikuti benda tersebut secara terus menerus di tangan siapapun benda itu berada. Perlindungan hak cipta sebagai hak kebendaan yang immaterial maka akan kembali kepada hak miliknya. Hak milik ini menjamin kepada pemilik untuk menikmati dengan bebas dan boleh pula melakukan tindakan hukum dengan bebas terhadap miliknya itu. Objek hak milik itu dapat berupa hak cipta sebagai hak kekayaan immateriil. Artinya bahwa buku pengetahuan merupakan hak kebendaan yang berhubungan langsung dengan kepemilikan dari pencipta atau pemilik dari suatu karya cipta tersebut, sehingga dapat merasakan hak eksklusif yang diberikan atas suatu karya cipta tersebut. Segala benda yang dilindungi oleh hak cipta termasuk buku pengetahuan, proses terjadinya perlindungan dan proses perlindungan yang diberikan merupakan hal-hal yang menyangkut konsep dasar perlindungan hak cipta (the basic concept of copyright protection).

Negara Indonesia lebih lazim menggunakan fair use/fair dealing dengan istilah pembatasan hak cipta. Berdasarkan pada ketentuan UU Hak Cipta tersebut pada Bab VI, pembatasan hak cipta (fair use/fair dealing), Pasal 43 s/d Pasal 49.23 Pasal 44 UU Hak Cipta menjelaskan:

a. Penggunaan, pengambilan, penggandaan, dan/atau pengubahan suatu ciptaan dan/atau produk hak terkait secara seluruh atau sebagian yang substansial tidak dianggap sebagai pelanggaran hak cipta jika sumbernya disebutkan atau dicantumkan secara lengkap untuk keperluan:

1. Pendidikan, penelitian, penulisan karya ilmiah, penyusunan laporan, penulisan kritik atau tinjauan suatu masalah dengan tidak merugikan kepentingan

23 Anis Mashdurohatun dan M. Ali Mansyur, 'Indentifikasi Fair Use/Fair Dealing Hak Cipta Atas Buku dalam Pengembangan IPTEK pada Pendidikan Tinggi di Jawa Tengah’ (2015) 4 Yustisia 522, 523. 
yang wajar dari pencipta atau Pemegang hak cipta;

2. keamanan serta penyelenggaraan pemerintahan, legislatif, dan peradilan;

3. ceramah yang hanya untuk tujuan pendidikan dan ilmu pengetahuan; atau

4. pertunjukan atau pementasan yang tidak dipungut bayaran dengan ketentuan tidak merugikan kepentingan yang wajar dari pencipta.

b. Fasilitasi akses atas suatu ciptaan untuk penyandang tuna netra, penyandang kerusakan penglihatan atau keterbatasan dalam membaca, dan/atau pengguna huruf braille, buku audio, atau sarana lainnya, tidak dianggap sebagai pelanggaran hak cipta jika sumbernya disebutkan atau dicantumkan secara lengkap, kecuali bersifat komersial.

c. Dalam hal ciptaan berupa karya arsitektur, pengubahan sebagaimana dimaksud pada ayat (1) tidak dianggap sebagai pelanggaran hak cipta jika dilakukan berdasarkan pertimbangan pelaksanaan teknis.

d. Ketentuan lebih lanjut mengenai fasilitasi akses terhadap ciptaan bagi penyandang tuna netra, penyandang kerusakan penglihatan dan keterbatasan dalam membaca dan menggunakan huruf braille, buku audio, atau sarana lainnya sebagaimana dimaksud pada ayat (2) diatur dengan Peraturan Pemerintah.

Pasal 46 UU ayat (2) huruf e UU Hak Cipta menjelaskan bahwa penggandaan untuk kepentingan pribadi sebagaimana dimaksud pada ayat (1) tidak mencakup, penggandaan untuk kepentingan pribadi yang pelaksanaannya bertentangan dengan kepentingan yang wajar dari pencipta atau pemegang hak cipta.

Penggandaan buku pengetahuan pada praktiknya bertujuan untuk mendapatkan kepentingan komersil, adapun hal tersebut bertentangan dengan kepentingan yang wajar dari pencipta atau pemegang hak cipta, sehingga penggandaan untuk kepentingan pribadi atas ciptaan yang telah dilakukan pengumuman yang hanya dapat dibuat sebanyak 1 (satu) salinan tanpa izin pencipta atau pemegang hak cipta disalahgunakan peruntukannya, oleh karenanya praktik pembajakan buku pengetahuan rawan terjadi di kalangan masyarakat Indonesia.

Doktrin fair use/fair dealing mengandung maksud tiga hal yakni: cara, tujuan, dan substansi dalam menggunakan hak cipta atas buku. Oleh karenanya aktivitas penggandaan buku dengan melakukan fotokopi sebagaimana banyak dilakukan mahasiswa dan tenaga pengajar di banyak perguruan tinggi walaupun dengan alasan untuk kepentingan pendidikan, apabila tidak mendasarkan pada tiga hal tersebut bisa jadi termasuk tindakan yang melanggar hak cipta. Terjadinya potensi pelanggaran hak cipta pada masyarakat, disebabkan salah dalam menafsirkan maupun ketidaktahuan atau kurangnya pemahaman HKI dan kultur masyarakat yang sangat berbeda. ${ }^{24}$ Ketentuan fair use/fair dealing hak cipta atas buku sebagaimana telah diamanahkan dalam 
ketentuan fair use/fair dealing hak cipta atas buku sebagaimana telah diamanahkan dalam UU Hak Cipta belum dapat dipahami secara menyeluruh oleh semua IKAPI sebagai penerbit buku. ${ }^{25}$

Sebagai bentuk perlindungan hukum hak cipta terhadap buku pengetahuan, pemerintah Indonesia menerapkan sanksi baik pidana maupun perdata. Adapun ketentuan pidana terkait dengan penggandaan atau pembajakan buku pengetahuan diatur dalam UU Hak Cipta sebagai berikut:

Pasal 113 ayat (3) UU Hak Cipta menjelaskan bahwa:

Setiap orang yang dengan tanpa hak dan/atau tanpa izin Pencipta atau pemegang Hak Cipta melakukan pelanggaran hak ekonomi Pencipta sebagaimana dimaksud dalam Pasal 9 ayat (1) huruf a, huruf b, huruf e, dan/atau huruf g untuk Penggunaan secara komersial dipidana dengan pidana penjara paling lama 4 (empat) tahun dan/atau pidana denda paling banyak Rp. 1.000.000.000,00 (satu miliar rupiah). Pasal 9 ayat (1) huruf a: penerbitan ciptaan, huruf b: penggandaan ciptaan dalam segala bentuknya, huruf e: pendistribusian ciptaan atau salinannya, huruf g: pengumuman ciptaan.

Pasal 113 ayat (4) UU Hak Cipta menjelaskan bahwa setiap orang yang memenuhi unsur sebagaimana dimaksud pada ayat (3) yang dilakukan dalam bentuk pembajakan, dipidana dengan pidana penjara paling lama 10 (sepuluh) tahun dan/atau pidana denda paling banyak Rp4.000.000.000,00 (empat miliar rupiah).

Pasal 114 UU Hak Cipta menyatakan bahwa"

\begin{abstract}
Setiap Orang yang mengelola tempat perdagangan dalam segala bentuknya yang dengan sengaja dan mengetahui membiarkan penjualan dan/atau penggandaan barang hasil pelanggaran Hak Cipta dan/atau Hak Terkait di tempat perdagangan yang dikelolanya sebagaimana dimaksud dalam Pasal 10, dipidana dengan pidana denda paling banyak Rp100.000.000,00 (seratus juta rupiah).
\end{abstract}

Adapun terkait dengan ganti kerugian yang disebabkan kerugian hak ekonomi dari pencipta atau pemegang hak cipta buku pengetahuan diatur pada Pasal 96 UU Hak Cipta. Pasal 96 ayat (1) UU Hak Cipta menjelaskan bahwa "Pencipta, pemegang Hak Cipta dan/atau pemegang Hak Terkait atau ahli warisnya yang mengalami kerugian hak ekonomi berhak memperoleh Ganti Rugi". Pasal 96 ayat (2) UU Hak Cipta menjelaskan bahwa "Ganti Rugi sebagaimana dimaksud pada ayat (1) diberikan dan dicantumkan sekaligus dalam amar putusan pengadilan tentang perkara tindak pidana Hak Cipta dan/atau Hak Terkait". Pasal 96 ayat (3) UU Hak Cipta menjelaskan bahwa "Pembayaran Ganti Rugi kepada Pencipta, Pemegang Hak Cipta dan/atau pemilik Hak Terkait dibayarkan paling lama 6 (enam) bulan setelah putusan pengadilan yang berkekuatan hukum tetap". Pasal 99 ayat (1) UU Hak Cipta menjelaskan "Pencipta, Pemegang Hak Cipta, atau pemilik Hak Terkait berhak mengajukan gugatan ganti rugi kepada Pengadilan Niaga atas pelanggaran Hak Cipta atau produk Hak Terkait”. Pasal 99 ayat (2) UU Hak Cipta menjelaskan "Gugatan ganti rugi sebagaimana dimaksud pada 
ayat (1) dapat berupa permintaan untuk menyerahkan seluruh atau sebagian penghasilan yang diperoleh dari penyelenggaraan ceramah, pertemuan ilmiah, pertunjukan atau pameran karya yang merupakan hasil pelanggaran hak cipta atau produk hak terkait". Pasal 99 ayat (3) UU Hak Cipta menjelaskan "Selain gugatan sebagaimana dimaksud pada ayat (1), pencipta, pemegang hak cipta, atau pemilik hak terkait dapat memohon putusan provisi atau putusan sela kepada Pengadilan Niaga untuk:

a. meminta penyitaan Ciptaan yang dilakukan Pengumuman atau Penggandaan, dan/atau alat Penggandaan yang digunakan untuk menghasilkan Ciptaan hasil pelanggaran Hak Cipta dan produk Hak Terkait; dan/atau

b. menghentikan kegiatan Pengumuman, Pendistribusian, Komunikasi, dan/atau Penggandaan Ciptaan yang merupakan hasil pelanggaran Hak Cipta dan produk Hak Terkait.

\section{Perlindungan Hukum Hak Cipta Buku Pengetahuan Yang Akan Datang}

Ketentuan fair use/fair dealing hak cipta atas buku di Indonesia diatur dalam ketentuan Pasal 44 Ayat (1) huruf $a$, huruf b dan huruf $c$, dalam Pasal ini diberikan perlindungan hak moral pencipta. Kemudian ketentuan Pasal 46 ayat (1) dan ayat (2) huruf b dan huruf e memberikan perlindungan ekonomi kepada pencipta/pemegang hak cipta. Berdasarkan ketentuan Pasal 47 UU Hak Cipta perpustakaan atau lembaga arsip yang tidak bertujuan komersial dapat membuat 1 (satu) salinan Ciptaan atau bagian Ciptaan tanpa izin Pencipta atau Pemegang Hak Cipta dengan syarat-syarat yang ketat.
Dari uraian diatas kriteria pembatasan dan pengecualian penggunaan hak cipta sebagai berikut:

1. Penggunaan hak cipta tanpa izin hanya untuk kepentingan non komersial

2. Penggunaan hak cipta tanpa izin untuk kepentingan pendidikan, penelitian dan pengembangan ilmu pengetahuan;

3. Penggunaan hak cipta tanpa izin diperbolehkan dengan mencantumkan sumbernya secara jelas dan lengkap;

4. Penggunaan hak cipta tanpa izin tidak dilakukan atas bagian yang paling substantial yang menjadi ciri khas dari karya cipta.

Selain dari ketentuan yang dijelaskan di atas maka tidak ada pengecualian atas penggunaan hak cipta tanpa seizin pemegang hak cipta atau pencipta atas buku pengetahuan, termasuk pula terkait dengan kepentingan untuk pendidikan yang dibatasi kewenangannya dengan tidak melakukan penggandaan dan/atau pembajakan atas hasil karya cipta buku pengetahuan tanpa seizin dari pencipta atau pemegang hak cipta.

Konsep hukum hak cipta buku pengetahuan di Indonesia pada saat ini belum dipahami dengan baik dalam kehidupan masyarakat. Dalam praktiknya, perlindungan hukum hak cipta buku pengetahuan masih menimbulkan berbagai pertentangan ataupun masalah-masalah terhadap pelaksanaan dalam perlindungan hukum hak cipta buku pengetahuan tersebut. Indonesia merupakan negara yang dikategorikan sebagai negara berkembang yang masih memerlukan pengembangan IPTEK 
yang masif guna menunjang kepentingan pengembangan sumber daya manusia agar dapat melakukan percepatan pembangunan di Indonesia, oleh karenanya diperlukan suatu upaya dari pemerintah untuk meningkatkan kesadaran masyarakat terkait dengan perlindungan hukum hak cipta buku pengetahuan guna melindungi hak eksklusif pencipta atau pemegang hak cipta. Hal ini bukanlah suatu pekerjaan yang mudah, selain dari pihak pemerintah diperlukan juga dukungan dari akademisi, mahasiswa, dan aparat penegak hukum serta pihak-pihak terkait untuk menegakan perlindungan terhadap hak cipta sebagaimana di atur di dalam UU Hak Cipta.

Permasalahan yang terjadi mengenai penegakan hukum atas hak cipta buku pengetahuan di Indonesia, tidak hanya dapat dilihat dari segi peraturan perundang-undangannya saja yang masih terdapat norma-norma hukum yang dapat ditafsirkan lain (multitafsir), namun juga terkait dengan permasalahan lemahnya penegakan hukum di bidang hak cipta terutama terhadap perlindungan hukum hak cipta buku pengetahuan. Kesadaran masyarakat dalam perlindungan hukum hak cipta buku pengetahuan yang masih kurang ini menyebabkan banyaknya terjadi pelanggaran terhadap buku pengetahuan seperti halnya penggandaan atau pembajakan buku pengetahuan yang menyebabkan kerugian terhadap pencipta atau pemegang hak cipta terutama terhadap hak eksklusif yang seharus- nya didapatkan. Kurang aktifnya pencipta atau pemegang hak cipta buku pengetahuan guna pemenuhan haknya sebagai pemegang hak terkait serta kurangnya peran pemerintah terhadap kebutuhan pendidikan dan minimnya pemahaman masyarakat Indonesia mengenai hak cipta, serta tuntutan ekonomi dikalangan masyarakat Indonesia yang lebih milih dengan cara yang mudah walaupun dilakukan dengan melanggar hukum menyebabkan maraknya pelanggaran hak cipta buku pengetahuan.

Namun di luar faktor-faktor yang telah dijelaskan di atas, kajian yang dilakukan terhadap UU Hak Cipta menunjukkan masih perlunya dilakukan beberapa penyempurnaan seperti sanksi yang dipertegas, penyempurnaan maksud, dan tujuan pembentukan organisasi profesi dan lain sebagainya sehingga mampu menangkal pelanggaran hak cipta tersebut. 26

Lawrence M. Friedman mengemukakan 3 fungsi sistem hukum yaitu: ${ }^{27}$ Pertama, sebagai bagian dari sistem kontrol sosial (social control) yang mengatur perilaku manusia. Kedua, sebagai sarana untuk menyelesaikan sengketa (dispute settlement). Ketiga, sistem hukum memiliki fungsi sebagai social engineering function, yaitu fungsi yang menekankan peranan hukum sebagai pemeliharaan "status quo" yang tidak menginginkan perubahan.

Dalam kaitannya dengan prospek perlindungan hukum terhadap suatu

26 Sophar Maru Hutagalung, Hak Cipta Kedudukan dan Peranan dalam Pembangunan (Sinar Grafika 2012) 1-3.

27 Lawrence M. Friedman, American Law, W.W. Norton \& Company, New York, 1984, p. 5-6 dalam Teguh Prasetyo dan Abdul Halim Barkatullah, Filsafat, Teori dan Hukum: Pemikiran Menuju Masyarakat yang Berkeadilan dan Bermartabat (Raja Grafindo Persada 2012) 311-312. 
hak cipta maka perlu dibentuk suatu badan negara yang bertujuan khusus untuk menangani hal-hal yang terkait dengan pembajakan terhadap hak cipta, badan negara tersebut dapat beranggotakan orang-orang yang mempunyai kompetensi di dalam masalah kak cipta, dapat berasal dari kepolisian, lawyer, satrawan, budayawan maupun akademisi. Pembentukan dari badan negara ini merupakan suatu terobosan baru yang diharapkan bisa menjadi suatu bentuk kepedulian pemerintah dalam melakukan penegakan hukum terhadap hak cipta terutama dalam perlindungan hukum hak cipta buku pengetahuan yang lebih baik serta mengefektifkan UU Hak Cipta, badan negara ini bisa memonitor segala bentuk kekurangan yang ada dalam UU Hak Cipta bila diterapkan di masyarakat, karena bagaimanapun juga ketentuan dalam pasal-pasal yang dirumuskan dalam peraturan perundangan akan selalu tertinggal dengan peristiwa hukum.

Apabila kita menafsirkan hukum secara progresif seperti yang dicetuskan oleh Prof. Satjipto Rahardjo membawa solusi untuk keluar dari belenggu hukum yang kaku. Intepretasi hukum bukan pada arti sebuah kalimat saja, namun dengan pemahaman pola pikir (mindset). Sehingga apabila ada peristiwa baru yang belum di atur secara eksplisit namun itu merupakan sebuah kejahatan dan sudah timbul korban. Modus dan motifnya pun jelas, maka tidak perlu menunggu sebuah aturan baru untuk membawa ke peradilan karena pemahaman seperti ini akan meminimalkan suatu peristiwa kekosongan hukum.

\section{PENUTUP}

Hak Cipta merupakan hak eksklusif bagi pencipta atau penerima hak untuk mengumumkan atau memperbanyak ciptaannya atau memberi ijin untuk itu dengan tidak mengurangi pembatasanpembatasan menurut peraturan perundang-undangan yang berlaku. Perlindungan terhadap suatu ciptaan timbul secara otomatis sejak ciptaan itu diwujudkan dalam bentuk nyata. Sebagai bentuk perlindungan hukum hak cipta terhadap buku pengetahuan, Pemerintah Indonesia menerapkan sanksi baik pidana maupun perdata. Meskipun sudah diatur sedemikian rupa namun masih banyak praktek penggandaan buku pengetahuan dengan tujuan untuk mendapatkan kepentingan komersil. Seiring berjalannya waktu pelanggaran yang dilakukan justru menjadi suatu kebiasaan masyarakat. Ini menandakan adanya ketidaksadaran dari masyarakat terutama di dunia pendidikan itu sendiri pada kususnya.

Adapun suatu kebiasaan yang dilakukan harusnya mulai disadari mengingat suatu dampak kedepannya. Perlindungan hukum hak cipta buku pengetahuan yang akan datang bila diawali dengan adanya kesadaran dan pemahaman tentang pentingnya atau berharganya suatu ciptaan dan kesadaran tentang batasan dalam melakukan penggandaan buku pengetahuan. Sehingga dari kesadaran itulah pemerintah mampu menyeimbangkan antara kepentingan dan perlindungan Hak Cipta buku pengetahuan dengan masyarakat pada umumnya.

Perlindungan hukum terhadap hasil 
karya cipta buku pengetahuan haruslah dapat dipahami oleh semua kalangan masyarakat Indonesia agar hak yang dimiliki oleh pencipta atau pemegang hak cipta buku pengetahuan, baik itu hak ekonomi maupun hak moral dapat terlindungi secara hukum. Perlindungan hukum ini dimaksudkan agar pencipta atau pemegang hak cipta tidak merasa dirugikan, oleh karenanya setiap masyarakat, aparat penegak hukum baik pihak kepolisian, kejaksaan, dan pengadilan serta pihak-pihak lain yang berkaitan untuk melindungi kepentingan dari buku pengetahuan tidak menyepelekan perlindungan hasil karya cipta buku pengetahuan sebagaimana diatur dalam UU Hak Cipta. Setiap ditemukannya pelanggaran terhadap hak cipta buku pengetahuan baiknya diberikan pemahaman terhadap orang yang melakukan pelanggaran tersebut agar kedepannya tidak melakukan hal serupa, hal ini merupakan upaya non penal agar setiap insan masyarakat mengetahui makna bahwa sanksi merupakan suatu hal yang tidak harus selalu dijatuhkan selama perbuatan yang dilakukan dapat dicegah serta tidak meimbulkan kerugian terhadap orang dalam hal ini adalah pencipta atau pemegang hak cipta. Prospek perlindungan hukum hak cipta buku pengetahuan layaknya berhubungan erat dengan penegakan hukum hak cipta buku pengetahuan. Oleh karenanya sinergitas antar para penegak hukum serta peran aktif masyarakat sangat diperlukan guna mengoptimalkan penegakan hukum terhadap pelanggaran buku pengetahuan terutama terkait dengan penggadaan dan/atau pembajakan buku pengetahuan tanpa izin pencipta atau pemegang hak cipta. Pengoptimalan ini dimaksudkan agar setiap tindak pidana terhadap hak cipta buku pengetahuan tidak sepelekan sebagai suatu hal kecil, karena hak cipta berhubungan dengan hak setiap manusia untuk menikmati hak yang di dapatkan dari suatu hasil karya cipta buku pengetahuan.

\section{DAFTAR BACAAN}

\section{Buku}

Arinanto, S., dan Triyanti, N., Memahami Hukum dari Konstruksi Sampai Implemantasi (PT. Raja Grafindo Persada 2001).

Asian Law Group Pty. Ltd., Hak Kekayaan Intelektual Suatu Pengantar (PT. Alumni 2011).

Djumhana dan Djubaedilah, R., Hak Milik Intelektual. (PT. Citra Aditya Bakti 2003).

Friedman, Lawrence M., American Law (W.W. Norton \& Company 1984)

Hadjon, Phillipus M., Perlindungan Hukum Bagi Rakyat Indonesia (PT. Bina Ilmu 1987).

Hasibuan, O., Hak Cipta di Indonesia (PT. Alumni 2014).

Lindsey, T., dkk, Hak Kekayaan Intelektual (Alumni 2011).

Prasetyo, T., dan Barkatullah, Abdul H., Filsafat Teori dan Hukum: Pemikiran Menuju Masyarakat yang Berkeadilan dan Bermartabat (Raja Grafindo Persada 2012).

Rahardjo, S., Ilmu Hukum (PT. Citra Aditya Bakti 2000).

Roisah, K., Konsep Hukum Hak Kekaya- 
aan Intelektual (HKI) (Setara Press 2015).

Rosalina, B., Perlindungan Karya Arsitektur Berdasarkan Hak Cipta (PT. Alumni 2010).

Saidin, Aspek Hukum Hak Atas Kekayaan Intelektual (PT. Raja Grafindo Persada 2010).

Sembiring, S., Hak Kekayaan Intelektual dalam Berbagai PerundangUndangan (Yrama Widya 2002).

Soelistyo, H., Hak Cipta Tanpa Hak Moral (Rajawali Pers 2011).

Sophar, Maru Hutagalung, Hak Cipta Kedudukan dan Peranan dalam Pembangunan (Sinar Grafika 2012).

Wignyosoebroto, S., Hukum: Paradigma, Metode, dan Dinamika Masalahnya (Huma 2002).

\section{Artikel Jurnal}

Akbar, Fajar A., 'Perlindungan Hukum Terhadap Hak Cipta Menurut Pasal 12 Undang-Undang nomor 28 Tahun 2014' (2016) 3 JOM Fakultas Hukum.

Kusmawan, D., 'Perlindungan Hak Cipta Atas Buku' (2014) 19 Jurnal Perspektif.

Marbun, Tommy H., dan Azwar, Keizeirina D., 'Perlindungan Hukum Hak Cipta Terhadap Karya Cipta Lagu dan Musik dalam Bentuk Ringtone Pada Telepone Seluler' (2013) 1 Transparency Jurnal Hukum Ekonomi.

Mashdurohatun, A., dan Mansyur, M. A., 'Indentifikasi Fair Use/Fair Dealing Hak Cipta Atas Buku dalam Pengembangan IPTEK pada
Pendidikan Tinggi di Jawa Tengah' (2015) 4 Yustisia.

Sitorus, Ade U., 'Hak Cipta dan Perpustakaan' (2015) 9 Jurnal Iqra.

\section{Peraturan Perundang-Undangan}

Undang-Undang Nomor 28 Tahun 2014 tentang Hak Cipta. 
